\title{
THE DISTRIBUTION OF THE ALIEN SPECIES PENAEUS AZTECUS IVES, 1891 (DECAPODA, PENAEIDAE) IN THE MEDITERRANEAN SEA
}

\author{
Tahir ÖZCAN *, Abdullah Suat ATEŞ ** and Gülnaz ÖZCAN * \\ * İskenderun Technical University, Faculty of Marine Sciences and Technology, İskenderun, Hatay, \\ Turkey, TR-31200, tahozcan@gmail.com, gulnazozcan@gmail.com \\ ** Çanakkale Onsekiz Mart University, Faculty of Marine Sciences and Technology, Çanakkale, \\ Turkey, TR-17100, asuatates@yahoo.com
}

DOI: $10.2478 /$ trser-2019-0011

KEYWORDS: brown shrimp, distribution, Mediterranean Sea.

\section{ABSTRACT}

The present paper is based on the literature review and the recent information about the distribution range of the alien brown shrimp Penaeus aztecus Ives, 1891 in the Mediterranean Sea. This alien species has spread throughout the Mediterranean Sea (especially the eastern part) mainly through ship/ballast water introductions and has presently been reported by eight countries (27 localities). Introduction pathways and chronological distribution patterns of the alien brown shrimp species are discussed. Penaeus aztecus forms dense populations along the coast of the Turkish Mediterranean Sea, and it has a potential for colonising the native habitats of autochthonous species.

ZUSAMMENFASSUNG: Die Verbreitung der fremdländischen Art Penaeus aztecus Ives, 1891 (Decapoda, Penaidae) im Mittelmeer.

Vorliegende Arbeit stützt sich auf eine Erfassung der Fachliteratur und auf rezente Informationen betreffend die im Mittelmeer eingebürgerte Art Penaeus aztecus Ives, 1891. Diese adventive Art hat sich im gesamten Mittelmeer, vor allem in dessen östlichem Teil vorwiegend durch Balastwasser der Schiffe ausgebreitet und wurde bereits aus acht Ländern insgesamt an 27 Orten gemeldet. Ebenso wurden die Verbreitungswege und das chronologische Verbreitungsmodell der Art dargestellt. Penaeus aztecus bildet dichte Populationen entlang der türkischen Mittelmeerküste und hat unter den invasiven Garnelenarten das Potential die Lebensräume der einheimischen Arten zu besiedeln.

REZUMAT: Distribuţia speciei străine Penaeus aztecus Ives, 1891 (Decapoda, Penaidae) în Marea Mediterană.

Prezenta lucrare se bazează pe o trecere în revistă a literaturii şi pe informaţii recente referitoare la distribuţia speciei adventive Penaeus aztecus Ives, 1891 din Marea Mediterană. Această specie adventivă s-a răspândit în întreaga Mediterană (în special în partea estică) în principal introdusă prin apa de balast a navelor şi a fost semnalată în opt ţări (27 de localităţi). Am prezentat de asemenea, căile de introducere şi modelul cronologic de distribuţie al acestei specii. Penaeus aztecus formează populaţii dense de-a lungul coastei Turce a Mării Mediterane. Între speciile invazive de creveți, Penaeus aztecus are potenţial de colonizare a habitatelor native ale speciilor autohtone. 


\section{INTRODUCTION}

The alien species invasions are one of the most important conservation issues around the world (Welcomme, 1988; Lodge et al., 1998; Strahm and Rietbergen, 2001; Lansdown et al., 2016; Anastasiu et al., 2017; *, GISD). Biological invasions of alien species constitute a significant environmental problem and one aspect of global change in the marine environment (Özcan et al., 2010; Katsanevakis et al., 2014; Galil et al., 2018). According to Galil et al. (2018) 726 alien marine species were listed in the Mediterranean Sea. An average of 10 alien species per year has penetrated in this sea (Galil, 2009).

The Mediterranean Sea is affected by invasive marine species by means of the Suez Canal. Most of pathways for the introduction of exotic species are via hull fouling and/or ballast water from ships (Özcan et al., 2010).

The brown shrimp Penaeus aztecus Ives, 1891 is commonly distributed throughout the north-western Atlantic Ocean (from Massachusetts to the Gulf of Mexico and the northwestern Yucatán) (Perez Farfante, 1969; Tavares, 2002).

The species was first recorded from the Antalya Bay, Levantine Sea coast of Turkey and it was hypothesized its introduction to the eastern Mediterranean Sea was due to ballast water (Deval et al., 2010). Then, it has been reported from the coast of Egypt (Sadek et al., 2018), Greece (Nikolopoulou et al., 2013), Montenegro (Marković et al., 2014), Italy (Cruscanti et al., 2015; Zava et al., 2018), Israel and France (Galil et al., 2017). Penaeus aztecus has also been reported from different localities of the Mediterranean Sea (Gökoğlu and Özvarol, 2013; Kapiris and Apostolidis, 2014; Zenetos and Giavasi, 2015; Minos et al., 2015; Bakır and Aydın, 2016; Kapiris and Minos, 2017; Kampouris et al., 2018; Zava et al., 2018). The economic importance of the zoogeographical distribution of this species in the Mediterranean Sea and its distribution in the İskenderun and Mersin Bays where areas of important shrimp fisheries are present.

\section{MATERIAL AND METHODS}

According to the existing literature (Web of Sciences, Google Scholar, Researchgate etc.) the zoogeographic distribution and expansion of Penaeus aztecus was attempting to be presented. In Turkey, the samplings were carried out in İskenderun and Mersin Bays between December 2010 and March 2017. The specimens of Penaeus aztecus were captured by means of trawl hauls on the sandy muddy seabed at depths of 20-35 m (Fig. 1). The specimens were identified using the keys in Perez Farfante $(1969,1988)$ and Tavares (2002). The specimens were preserved in $4 \%$ formalin and deposited at the Faculty of Marine Sciences and Technology of the Iskenderun Technical University, Turkey (collection of Dr. T. Özcan).

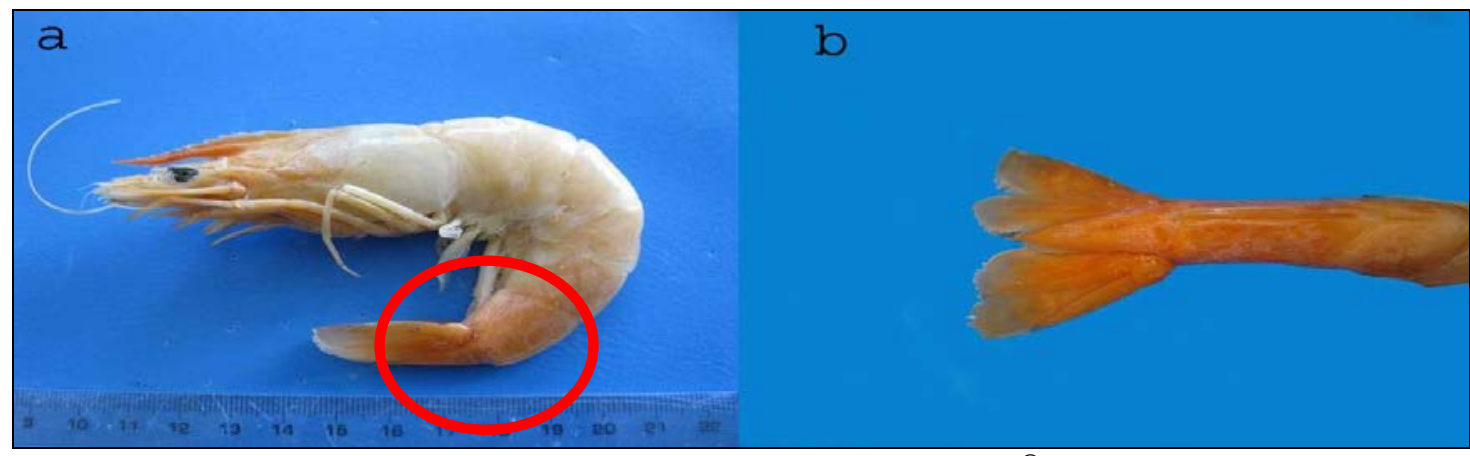

Figure 1: Penaeus aztecus a: Lateral view, $q \mathrm{~mm}$;

b: Dorsal view of sixth abdominal somite, telson and uropods. 


\section{RESULTS AND DISCUSSION}

Recently, Penaeus aztecus has been one of the species that has rapidly entered in the Mediterranean Sea (Zava et al., 2018). The distribution area of this species in this sea has expanded. Previous local records of Penaeus aztecus on the Turkish Mediterranean coast were given from the Bays of Antalya, Mersin, and İskenderun (west side: Yumurtalık Bight) (Gökoğlu and Ozvarol, 2013). Penaeus aztecus is denser in the Yumurtalık-Karataş region within the Iskenderun Bay and it is predicted to be evaluated economically in terms of its population size. After one year, the species first reported in Turkey has expanded to the Finike coast and the Iskenderun Bay increasing its expansion area by approximately $500 \mathrm{~km}$ (Gökoğlu and Özvarol, 2013). Penaeus aztecus was reported on the shores of Damietta Egypt (Sadek et al., 2018) and Thermaikos Gulf, Greece (Nikolopoulou et al., 2013) after one year due to introduction by ship ballast waters. The expansion between 2013 and 2018 are as follows; Boka Kotorska Bay, Adriatic Sea, Montenegro (Marković et al., 2014), Corfu Island, Ionian Sea, Greece (Kapiris and Apostolidis, 2014), Thermaikos Gulf (Kevrekidis, 2014) and Nestos estuaries, Aegean Sea, Yunanistan (Minos et al., 2015), Castiglione della Pescaia, Tyrrhenian Italy (Cruscanti et al., 2015), Kyllini (Zenetos and Giavasi, 2015) and Chalki Island, Greece (Kondylatos and Corsini-Foka, 2015), Gulf of Lion (France), Israeli coast (Galil et al., 2017), Sicily between Porto Empedocle and Mazara del Vallo, Italy (Scannella et al., 2017); Vivari Lagoon, Argolikos Gulf-Greece, Aegean Sea (Kapiris and Minos, 2017); Çandarlı and Ildır Bay, Aegean Sea, Turkey (Bakır and Aydın, 2016); Chieti, Ortona, Mola di Bari and Termoli, Adriatic Sea (Zava et al., 2018) and Vlora Bay-Albania, Adriatic Sea and Marzamemi, Ionian coast of Sicily (Kampouris et al., 2018) (Fig. 2 and Tab. 1).

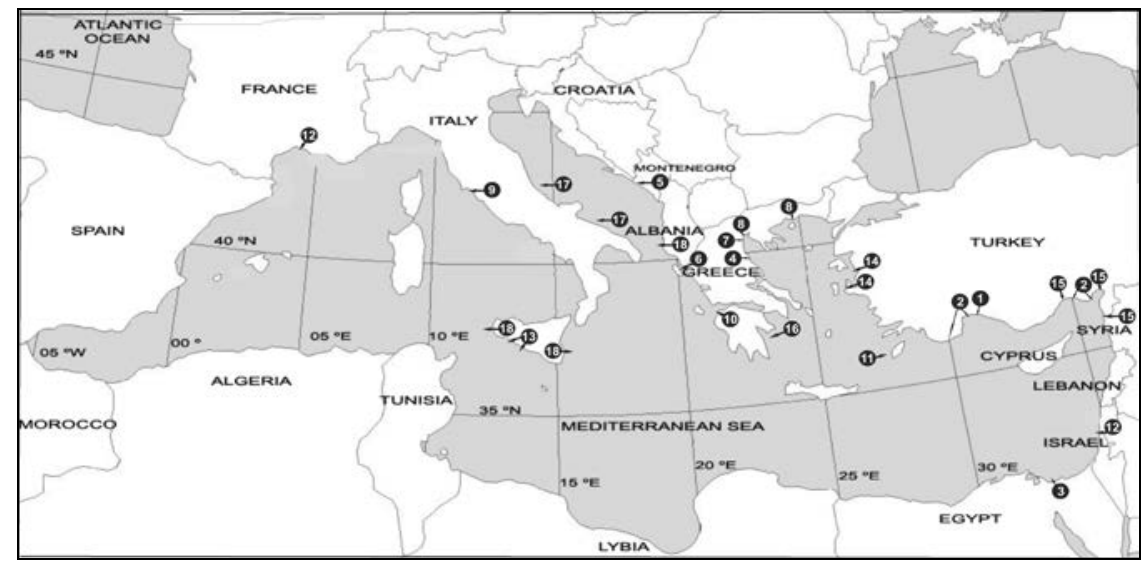

Figure 2: Current map showing distribution locations of records of Penaeus aztecus in the Mediterranean Sea, in chronological order: 1: (Deval et al. 2010); 2: (Gökoğlu and Özvarol 2013); 3: (Sadek et al. 2017); 4: (Nikolopoulou et al. 2013); 5: (Marković et al. 2013);

6: (Kapiris and Apostolidis, 2014); 7: (Kevrekidis 2014); 8: (Minos et al. 2015); 9: (Cruscanti et al. 2015); 10: (Zenetos and Giavasi, 2015); 11: (Kondylatos and Corsini-Foka, 2015);

12: (Galil et al., 2016); 13: (Scannella et al., 2017); 14: (Bakır and Aydın, 2016); 15: (Present study); 16: (Kapiris and Minos, 2017); 17: (Zava et al., 2018); 18: (Kampouris et al., 2018). For details see table 1.

According to Deval et al. (2010), Penaeus aztecus was captured with native and lessepsian species in the İskenderun and Mersin Bay. After Penaeus aztecus was reported for the first time in Antalya Bay, in eight years, its distribution in the Mediterranean was expanded. 
Table 1: Chronological distribution of Penaeus aztecus found in the Mediterranean Sea.

\begin{tabular}{|c|c|c|c|}
\hline No. & Authors & Region & Date reported \\
\hline 1. & $\begin{array}{l}\text { Deval et al., } \\
2010\end{array}$ & $\begin{array}{l}\text { Antalya, } \\
\text { Turkey }\end{array}$ & $\begin{array}{l}24 \text { December } \\
2009\end{array}$ \\
\hline 2. & $\begin{array}{c}\text { Gökoğlu and Ozvarol, } \\
2013\end{array}$ & $\begin{array}{c}\text { Finike, İskenderun Bay, } \\
\text { Turkey }\end{array}$ & $\begin{array}{l}\text { June } \\
2011\end{array}$ \\
\hline 3. & $\begin{array}{c}\text { Sadek et al., } \\
2018\end{array}$ & $\begin{array}{c}\text { Damietta, } \\
\text { Egypt }\end{array}$ & 2012 \\
\hline 4. & $\begin{array}{c}\text { N1kolopoulou et al., } \\
2013\end{array}$ & $\begin{array}{c}\text { Thermaikos Gulf, } \\
\text { Greece }\end{array}$ & 2012 \\
\hline 5. & $\begin{array}{c}\text { Marković et al., } \\
2014\end{array}$ & $\begin{array}{c}\text { Boka Kotorska Bay, } \\
\text { Montenegro }\end{array}$ & $\begin{array}{c}19 \text { September } \\
2013\end{array}$ \\
\hline 6. & $\begin{array}{l}\text { Kapiris and Apostolidis, } \\
2014\end{array}$ & $\begin{array}{l}\text { Corfu Island, } \\
\text { Greece }\end{array}$ & $\begin{array}{l}\text { November } \\
2013\end{array}$ \\
\hline 7. & $\begin{array}{c}\text { Kevrekidis, } \\
2014\end{array}$ & $\begin{array}{l}\text { Thermaikos Gulf, } \\
\text { Greece }\end{array}$ & $\begin{array}{c}22 \text { November } \\
2013\end{array}$ \\
\hline 8. & $\begin{array}{l}\text { Minos et al., } \\
2015\end{array}$ & $\begin{array}{l}\text { Thermaikos Gulf and } \\
\text { Nestos estuaries, Greece }\end{array}$ & $\begin{array}{c}\text { November } 2013 \text { to March } \\
2014\end{array}$ \\
\hline 9. & $\begin{array}{l}\text { Cruscanti et al., } \\
2015\end{array}$ & $\begin{array}{l}\text { Castiglione della Pescaia, } \\
\text { Italy }\end{array}$ & $\begin{array}{c}\text { 6th August } \\
2014\end{array}$ \\
\hline 10. & $\begin{array}{c}\text { Zenetos and Giavasi, } \\
2015\end{array}$ & $\begin{array}{l}\text { Kyllini, } \\
\text { Greece }\end{array}$ & $\begin{array}{c}\text { October } \\
2014\end{array}$ \\
\hline 11. & $\begin{array}{c}\text { Kondylatos and Corsini- } \\
\text { Foka, } 2015\end{array}$ & $\begin{array}{c}\text { Chalki Island, } \\
\text { Greece }\end{array}$ & $\begin{array}{l}\text { 1st November } \\
2014\end{array}$ \\
\hline 12. & $\begin{array}{c}\text { Galil et al., } \\
2017 \\
\end{array}$ & $\begin{array}{l}\text { Le Grau du Roi, Gulf of } \\
\text { Lion, France and Israel }\end{array}$ & $\begin{array}{c}30 \text { April } \\
2015 \\
\end{array}$ \\
\hline 13. & $\begin{array}{l}\text { Scannella et al., } \\
2017\end{array}$ & $\begin{array}{c}\text { Sicily between Porto } \\
\text { Empedocle and Mazara } \\
\text { del Vallo, Italy }\end{array}$ & $\begin{array}{l}\text { 3rd November } \\
2015\end{array}$ \\
\hline 14. & $\begin{array}{l}\text { Bakır and Aydın, } \\
2016\end{array}$ & $\begin{array}{c}\text { Çandarlı Bay and Ildır } \\
\text { Bay, Turkey }\end{array}$ & $\begin{array}{l}\text { December } 2015 \text { to } \\
\text { February } 2016\end{array}$ \\
\hline 15. & Present study & $\begin{array}{l}\text { Mersin Bay, İskenderun } \\
\text { Bay, Turkey }\end{array}$ & $\begin{array}{l}\text { December } 2010 \\
\text { to March } 2017\end{array}$ \\
\hline 16. & $\begin{array}{c}\text { Kapiris and Minos, } \\
2017 \\
\end{array}$ & $\begin{array}{l}\text { Vivari Lagoon, Argolikos } \\
\text { Gulf-Greece, Aegean Sea }\end{array}$ & 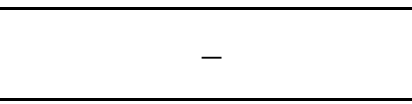 \\
\hline 17. & $\begin{array}{l}\text { Zava et al., } \\
2018\end{array}$ & $\begin{array}{c}\text { Chieti, Ortona, Mola di } \\
\text { Bari, Adriatic Sea } \\
\text { Termoli, Adriatic Sea } \\
\end{array}$ & $\begin{array}{c}\text { 2015, } \\
\text { December 2016, } \\
\text { November 2017 }\end{array}$ \\
\hline 18. & $\begin{array}{l}\text { Kampouris et al., } \\
2018\end{array}$ & $\begin{array}{c}\text { Vlora Bay-Albania, } \\
\text { Adriatic Sea; Marzamemi, } \\
\text { Ionian coast of Sicily; } \\
\text { Mazara del Vallo to } \\
\text { Pozzallo }\end{array}$ & $\begin{array}{c}21 \text { May } \\
\text { and } \\
\text { 2nd June } 2018 \\
\text { 24 March } \\
\text { 2018 }\end{array}$ \\
\hline
\end{tabular}




\section{CONCLUSIONS}

Recent studies reported that Penaeus aztecus which extends the distribution area in the Mediterranean, may have a potential negative effect on the native species of the Mediterranean such as Penaeus kerathurus (Kevrekidis, 2014). Consequently, it is likely that the existing shrimp species will start to compete with other shrimp species in the Mediterranean Sea. It is known, Penaeus aztecus prefers the coastal areas so many bays and estuaries in the Mediterranean ecosystem are suitable habitats for this species. Penaeus aztecus competes with many native and exotic species in the eastern Mediterranean (Kevrekidis, 2014).

The eastern Mediterranean Sea (particularly Iskenderun Bay) is affected by invasion of exotic shrimps via Suez Canal and hull fouling and/or ballast water from ships. Due to that, most of scientific surveys should be performed in İskenderun Bay to have a detailed understanding about the impact exotics have on native species or competition between native and exotic species. Yet, we need to carry out the surveys in areas economically affecting shrimp fisheries in the Iskenderun Bay and Mediterranean Sea. 


\section{ACKNOWLEDGEMENTS}

We would like to thank the vessel "F/V-Tuana 1" captain and crews for their support in sampling and sorting the biological capture. 


\section{REFERENCES}

1. Anastasiu P., Preda C., Bănăduc D. and Cogălniceanu D., 2017 - Alien species of European Union concern in Romania, Transylvanian Review of Systematical and Ecological Research, 19.3, The Wetlands Diversity, ISSN-L 1841-7051, ISSN 2344-3219, 93-106.

2. Bakır K. and Aydın I., 2016 - New localities in the Aegean Sea for alien shrimps Penaeus aztecus (Ives, 1891) and Metapenaeus affinis (H. Milne Edwards, 1837), Acta Adriatica, 57, 2, 273-280.

3. Cruscanti M., Innocenti G., Alvarado Bremer J. and Galil B. S., 2015 - First report of the brown shrimp Penaeus aztecus Ives, 1891 (Crustacea, Decapoda, Penaeidae) in the Tyrrhenian Sea, Marine Biodiversity Records, 8, e81.

4. Deval M. C., Kaya Y., Güven O., Gokoğlu M. and Froglia C., 2010 - An unexpected find of the western Atlantic shrimp, Farfantepenaeus aztecus (Ives, 1891) (Decapoda, Penaeidae) in Antalya Bay, eastern Mediterranean Sea, Crustaceana, 83, 12, 1531-1537.

5. Galil B. S., 2009 - Taking stock: inventory of alien species in the Mediterranean Sea, Biological Invasions, 11, 2, 359-372.

6. Galil B. S., Innocenti G., Douek J., Paz G. and Rinkevich B., 2017 - Foul play? On the rapid spread of the brown shrimp Penaeus aztecus Ives, 1891 (Crustacea, Decapoda, Penaeidae) in the Mediterranean, with new records from the Gulf of Lion and the southern Levant, Marine Biodiversity, 47, 979-985.

7. Galil B. S., Marchini A. and Occhipinti-Ambrogi A., 2018 - East is east and West is west? Management of marine bioinvasions in the Mediterranean Sea, Estuarine, Coastal and Shelf Science, 201, 7-16.

8. Gökoğlu M. and Ovzarol Y., 2013 - Biogeographic expansion of Farfantepenaeus aztecus (Ives, 1891) (Decapoda, Penaeidea) in the eastern Mediterranean, 475-476, in Bilecenoglu et al., 2013, New Mediterranean Marine biodiversity records (December, 2013), Mediterranean Marine Science, 14, 2, 463-480.

9. Kampouris T. E., Tiralongo F., Golemaj A., Giovos I., Doumpas N. and Batjakas I. E., 2018 Penaeus aztecus Ives, 1891 (Decapoda, Dendrobranchiata, Penaeidae): On the range expansion in Sicilian waters and on the first record from Albanian coast, International Journal of Fisheries and Aquatic Studies, 6, 4, 468-471.

10. Kapiris K. and Apostolidis C., 2014 - Farfantepenaeus aztecus: a new alien decapod in the Ionian Sea, 209, in Kapiris et al., 2014, New Mediterranean Marine biodiversity records (April, 2014), Mediterranean Marine Science 15, 1, 198-212.

11. Kapiris K. and Minos G., 2017 - Weight-length relationship of the northern brown shrimp Penaeus aztecus Ives, 1891 (Decapoda: Penaeidae) from the Central Aegean Sea, Greece, Mediterranean Marine Science, 18, 3, 562-563.

12. Katsanevakis S., Coll M., Piroddi C., Steenbeek J., Ben Rais Lasram F., Zenetos A. and Cardoso A. C., 2014 - Invading the Mediterranean Sea: biodiversity patterns shaped by human activities, Frontiers in Marine Science, 1, 32, doi: 10.3389/fmars.2014.00032, in printing.

13. Kevrekidis K., 2014 - The occurrence of the Atlantic penaeid prawn Farfantepenaeus aztecus (Ives, 1891) in the Thermaikos Gulf (Aegean Sea, eastern Mediterranean): considerations on the potential establishment and impact on the autochthonous Melicertus kerathurus (Forskål, 1775). Crustaceana, 87, 1606-1619.

14. Kondylatos G. and Corsini-Foka M., 2015 - First record of Penaeus aztecus Ives, 1891 (Crustacea, Decapoda) and Melibe viridis (Kelaart, 1858) (Gastropoda, Nudibranchia) in the South-Eastern Aegean Sea (Greece), Mediterranean Marine Science, 16, 1, 278-279.

15. Marković O., Gökoğlu M., Petović S. and Mandić M., 2014 - First record of the Northern brown shrimp, Farfantepenaeus aztecus (Ives, 1891) (Crustacea: Decapoda: Penaeidae) in the South Adriatic Sea, Montenegro, Mediterranean Marine Science, 15, 1, 165-167. 
16. Minos G., Kokokiris L., Imsiridou A., Karachle P. and Kapiris K., 2015 - Notes on the distribution and biology of northern brown shrimp Farfantepenaeus aztecus (Ives, 1891) in the Eastern Mediterranean, Turkish Journal of Zoology, 39, 1-7.

17. Nikolopoulou I., Baxevanis A. D., Kampouris T. E. and Abatzopoulos T. J., 2013 Farfantepenaeus aztecus (Ives, 1891) (Crustacea: Decapoda: Penaeidae) in N Aegean: first record in Greece by morphological and genetic features, Journal of Biological Research, 20, 367-375.

18. Lansdown R., Anastasiu P., Barina Z., Bazos I., Çakan H., Cakovic D., Delipetrou P., Matevski V., Mitic B., Ruprecht E., Tomovic G., Tosheva A. and Kiraly G., 2016 - Review of Alien Freshwater Vascular Plants in South-East Europe, 141-158, in Rat M., Trichkova T., Scalera R., Tomov R. and Uludag A. (eds) ESENIAS Report 2015 - State of the Art of Invasive Alien Species in South-Eastern Europe, publishers University of Novi Sad Faculty of Sciences, Department of Biology and Ecology, Novi Sad, Serbia, East and South European Network for Invasive Alien Species, Sofia, Bulgaria, ISBN 978-86-7031-3316.

19. Lodge D. M., Stein R. A., Brown K. M., Covich A. P., Bronmark C., Garvey J. E. and Klosiewski S. P., 1998 - Predicting impact of freshwater exotic species on native biodiversity: challenges in spatial scaling, Australian Journal of Ecology, 23, 53-67.

20. Özcan T., Katağan T. and Peter K. N. L., 2010 - First record of Eurycarcinus integrifrons De Man 1879 (Decapoda, Pilumnidae) from the Mediterranean Sea, Crustaceana, 83, 4, 507-510.

21. Perez Farfante I., 1969 - Western Atlantic shrimps of the genus Penaeus, Fishery Bulletin, U.S., 67, 3, i-x, 461-591.

22. Perez Farfante I., 1988 - Illustrated key to penaeoid shrimps of commerce in the Americas, NOAA Technical Report, NMFS, 64, i-iv, 1-32.

23. Sadek S., Abou El-Soud W. and Galil B. S., 2018 - The brown shrimp Penaeus aztecus Ives, 1891 (Crustacea, Decapoda, Penaeidae) in the Nile Delta, Egypt: an exploitable resource for fishery and mariculture? BioInvasions Records, 7, 1, 51-54.

24. Scannella D., Falsone F., Geraci M. L., Froglia C., Fiorentino F., Giusto G. B., Zava B., Insacco G. and Colloca F., 2017 - First report of Northern brown shrimp Penaeus aztecus Ives, 1891 in Strait of Sicily, BioInvasions Records, 6, 1, 67-72.

25. Strahm W. and Rietbergen S., 2001 - Alien invasions from our own planet, IUCN European Programme Newsletter, 27, September, Praha, 3.

26. Tavares M., 2002 - Shrimps, 251-291, in Carpenter K. E. (ed.) The living marine resources of the Western Central Atlantic, 1, introdution, molluscs, crustaceans, hagfishes, sharks, batoid fishes, and chimaeras, FAO Species Identification Guide for Fishery Purposes and American Society of Ichthyologists and Herpetologists Special Publication, 5, Rome, FAO, 1-600.

27. Zava B., Insacco G. and Galil B. S., 2018 - The first record of the brown shrimp Penaeus aztecus Ives, 1891 in the central Adriatic coast of Italy, BioInvasions Records, 7, 3, 293-296.

28. Zenetos A. and Giavasi M., 2015 - Penaeus aztecus establishing in the Greek Ionian Sea, New Mediterranean biodiversity records (October 2015), Mediterranean Marine Science, 16, 691.

29. Welcomme R. L., 1988 - International introductions of inland aquatic species, FAO Fish Technical Paper, 294, 318.

30. * GISD - Global Invasive Species Database http://www.iucngisd.org/gisd/ 